\title{
Maternal anticonvulsants and optic nerve hypoplasia
}

\author{
CREIG S. HOYT AND FRANK A. BILLSON \\ From the Department of Ophthalmology, University of Sidney, Sydney Eye Hospital, Australia
}

SUMMARY Seven patients with optic nerve hypoplasia, born of epileptic mothers, are presented. All the mothers took anticonvulsants during pregnancy. The possibility that maternal anticonvulsant therapy may play a role in the genesis of optic nerve hypoplasia is discussed in the light of what is known about the teratogenicity of these agents.

Optic nerve hypoplasia is a developmental anomaly which probably originates as the consequence of defective differentiation of the retinal ganglion cell layer (Duke-Elder, 1963). Although it was once thought to be a rare anomaly, since the reports of Walton and Robb (1970) and Edwards and Layden (1970), optic nerve hypoplasia has been recognised with increasing frequency. In 1972 we reported 10 cases seen over 18 months (Billson, 1972; Billson and Hopkins, 1972), and since that time we have seen a further 57 cases.

Very little is known about the causative factors responsible for this developmental defect. The great majority of cases are sporadic, although a few familial cases have been documented (Missiroli, 1947; Kytilä and Miettingen, 1961; and Hackenbruch et al., 1975). Optic nerve hypoplasia has been reported as a consequence of maternal quinine ingestion (McKinna, 1966) and in association with maternal diabetes mellitus (Petersen and Walton, 1977). In cattle optic nerve hypoplasia has been associated with bovine-mucosal disease virus (Bistner et al., 1973). The common feature of the 7 patients reported in this paper is that all the mothers were epileptic and took anticonvulsants during pregnancy. The possibility that anticonvulsants may be an aetiological factor in some cases of optic nerve hypoplasia is discussed in the light of what is known about the teratogenicity of anticonvulsants.

\section{Methods and patients}

Sixty-seven patients with optic nerve hypoplasia were examined at the Royal Children's Hospital, Melbourne, or in the private practice of one of us

Address for reprints: Miss Eugenia Lovelace, Librarian, Sydney Eye Hospital, Sir John Young Crescent, Woolloomooloo, New South Wales 2011, Australia
(F.A.B.), from January 1970 to January 1977. To evaluate if any maternal factors might be responsible for some cases of optic nerve hypoplasia a retrospective study of the medical records of these 67 patients was undertaken. We found that in 7 of the 67 cases there was a history of maternal epilepsy and anticonvulsant therapy during pregnancy. The clinical details of these 7 patients constitute this report.

\section{REPORT OF CASES}

In Tables 1 and 2 the clinical findings of the 7 patients are summarised, and in Figs. 1 to 3 the condition in 3 patients is illustrated. Four of the patients were female and 3 were male. Six patients had bilateral optic nerve hypoplasia, and 1 had only unilateral involvement. The central visual acuities in the affected eyes ranged from $6 / 9$ to $6 / 60$. In 2 patients no estimation of visual acuity was possible, since they died within the first month of life. The ophthalmoscopic appearance of the optic discs varied from very small, pale discs to nearly normalsized discs with no pallor. The retinal vasculature appeared normal in all cases. Nonocular abnormalities were present in 4 cases. These anomalies included ventricular septal defect, cleft palate, hypoplasia of the kidneys, coronal hypospadias, atresia of the ureters, and microcephaly.

The mothers of all 7 children suffered from epileptic seizures and were taking anticonvulsant medication throughous the pregnancies. Two of the mothers were free of seizures during pregnancy, and none of them experienced more than 3 seizures per month. All of the mothers were taking phenytoin. Two were also taking phenobarbitone, and 1 was also taking diazepam. Optic nerve hypoplasia was not found in more than 1 offspring of any of the epileptic mothers. However, 3 of the mothers had experienced at least 1 spontaneous abortion. A 
Table 1 Clinical findings in 7 patients

\begin{tabular}{|c|c|c|c|c|c|c|}
\hline Case & $\operatorname{Sex}$ & Eye & Visual acuity & Disc appearance & Other ocular anomalies & Systemic anomalies \\
\hline 1 & $\mathbf{M}$ & Bilateral & 一 & $\begin{array}{l}\text { Less than one-third } \\
\text { normal size and } \\
\text { extremely pale }\end{array}$ & - & $\begin{array}{l}\text { Cleft palate, ventricular septal } \\
\text { defect, hypoplastic left heart } \\
\text { syndrome }\end{array}$ \\
\hline 2 & $\mathbf{F}$ & Bilateral & 一 & $\begin{array}{l}\text { One-third normal size } \\
\text { and very pale }\end{array}$ & Microphthalmos & $\begin{array}{l}\text { Cleft palate, ventricular septal } \\
\text { defect, hypoplastic kidneys, } \\
\text { atresia of ureters }\end{array}$ \\
\hline 3 & $\mathbf{F}$ & Bilateral & $\begin{array}{l}\text { OD }>6 / 60 \\
\text { OS } 6 / 36\end{array}$ & Half normal size and pale & $\begin{array}{l}\text { Alternating esotropia } \\
10 \text { to } 12^{\circ}\end{array}$ & $\begin{array}{l}\text { Ventricular septal defect, } \\
\text { microcephaly }\end{array}$ \\
\hline 4 & $\mathbf{F}$ & Bilateral & $\begin{array}{ll}\text { OD } & 6 / 36 \\
\text { OS } & 6 / 36\end{array}$ & Half normal size and pale & - & - \\
\hline 5 & $\mathbf{M}$ & Bilateral & $\begin{array}{ll}\text { OD } & 6 / 36 \\
\text { OS } & 6 / 12\end{array}$ & $\begin{array}{l}\text { Half normal size, } \\
\text { normal colour }\end{array}$ & Intermittent exotropia & Coronal hypospadias \\
\hline 6 & $\mathbf{M}$ & Bilateral & $\begin{array}{ll}\text { OD } & 6 / 60 \\
\text { OS } & 6 / 9\end{array}$ & $\begin{array}{l}\text { Right one-third normal size } \\
\text { Left two-thirds normal size. } \\
\text { Both are pale }\end{array}$ & Right esotropia 15 to $20^{\circ}$ & - \\
\hline 7 & $\mathbf{F}$ & $\begin{array}{l}\text { Unilateral } \\
\text { Left }\end{array}$ & $\begin{array}{ll}\text { OD } & 6 / 6 \\
\text { OS } & 6 / 60\end{array}$ & $\begin{array}{l}\text { Left disc is one-third } \\
\text { normal size }\end{array}$ & Left esotropia $25^{\circ}$ & - \\
\hline
\end{tabular}

Table 2 Clinical findings in 7 patients

\begin{tabular}{|c|c|c|c|}
\hline Case & $\begin{array}{l}\text { Developmental } \\
\text { history }\end{array}$ & $\begin{array}{l}\text { Seizure history of } \\
\text { mother }\end{array}$ & $\begin{array}{l}\text { Total daily dosage of } \\
\text { anticonvulsants during } \\
\text { pregnancy }\end{array}$ \\
\hline 1 & $\begin{array}{l}\text { Died of cardiac } \\
\text { failure at } 3 \\
\text { weeks of age }\end{array}$ & $\begin{array}{l}2 \text { Grand mal } \\
\text { seizures during } \\
\text { the sixth month } \\
\text { of pregnancy }\end{array}$ & Phenytoin $300 \mathrm{mg}$ \\
\hline 2 & $\begin{array}{l}\text { Died of renal } \\
\text { failure at } 40 \\
\text { hours }\end{array}$ & $\begin{array}{l}\text { No seizures during } \\
\text { pregnancy }\end{array}$ & $\begin{array}{l}\text { Phenytoin } 300 \mathrm{mg} \text {, } \\
\text { Phenobarbitone } 60 \mathrm{mg}\end{array}$ \\
\hline 3 & $\begin{array}{l}\text { Very slow in } \\
\text { motor develop- } \\
\text { ment. Still does } \\
\text { not stand at } \\
2 \text { years of age }\end{array}$ & $\begin{array}{l}1 \text { Grand mal } \\
\text { seizure during } \\
\text { the third month }\end{array}$ & Phenytoin $300 \mathrm{mg}$ \\
\hline 4 & $\begin{array}{l}\text { Normal except for } \\
\text { visual problem } \\
\text { at } 4 \text { years of age }\end{array}$ & $\begin{array}{l}2 \text { to } 3 \text { Grand mal } \\
\text { seizures } 1 \text { month }\end{array}$ & $\begin{array}{l}\text { Phenytoin } 400 \mathrm{mg} \\
\text { Phenobarbitone } 90 \mathrm{mg}\end{array}$ \\
\hline 5 & $\begin{array}{l}\text { Average perform- } \\
\text { ance in normal } \\
\text { school at } 7 \text { years } \\
\text { of age }\end{array}$ & $\begin{array}{l}\text { No seizures during } \\
\text { pregnancy }\end{array}$ & Phenytoin $300 \mathrm{mg}$ \\
\hline 6 & $\begin{array}{l}\text { Normal develop- } \\
\text { ment at } 3 \text { years } \\
\text { of age }\end{array}$ & $\begin{array}{l}2 \text { Grand mal } \\
\text { seizures during } \\
\text { pregnancy }\end{array}$ & Phenytoin $300 \mathrm{mg}$ \\
\hline 7 & $\begin{array}{l}\text { Normal at } 7 \text { years } \\
\text { of age }\end{array}$ & $\begin{array}{l}3 \text { Grand mal } \\
\text { seizures during } \\
\text { pregnancy }\end{array}$ & $\begin{array}{l}\text { Phenytoin } 300 \mathrm{mg} \\
\text { Diazepam } 30 \mathrm{mg}\end{array}$ \\
\hline
\end{tabular}

sibling of case 1 had a cleft lip, and a sibling of case 3 had a ventricular septal defect.

\section{Discussion}

In 1975 we drew attention to variability of appearance of optic nerve hypoplasia in association with visual defect (Billson, 1975). However, Petersen and Walton (1977) have recently emphasised that normal central visual acuity is not incompatible with hypoplasia of the optic nerve. This is in direct contrast with previously established criteria, which

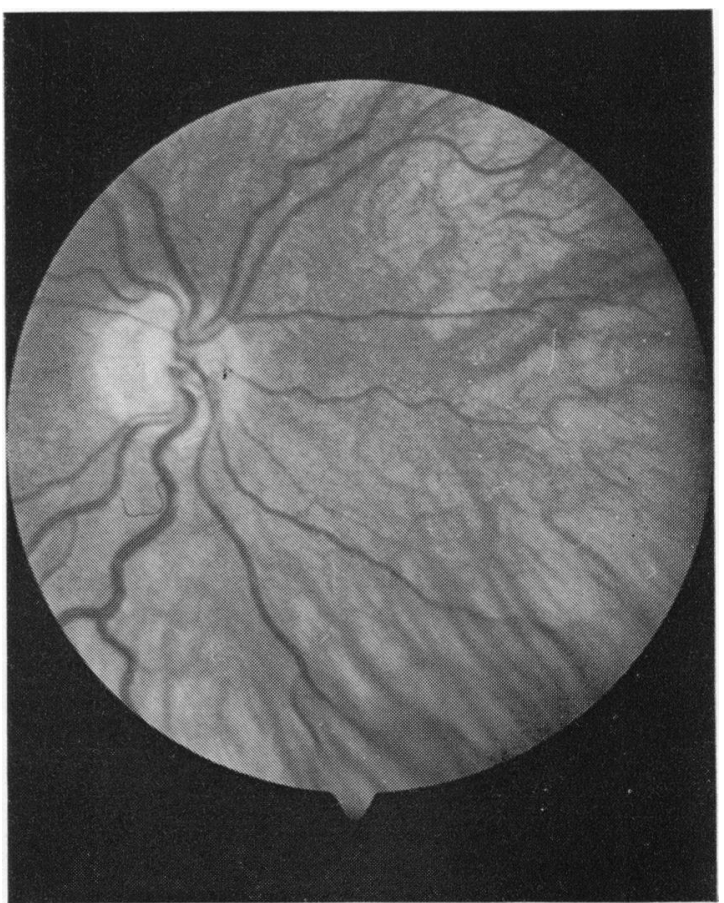

Fig. 1 Optic nerve of the right eye in case 3. Note the scleral ring round the small disc 


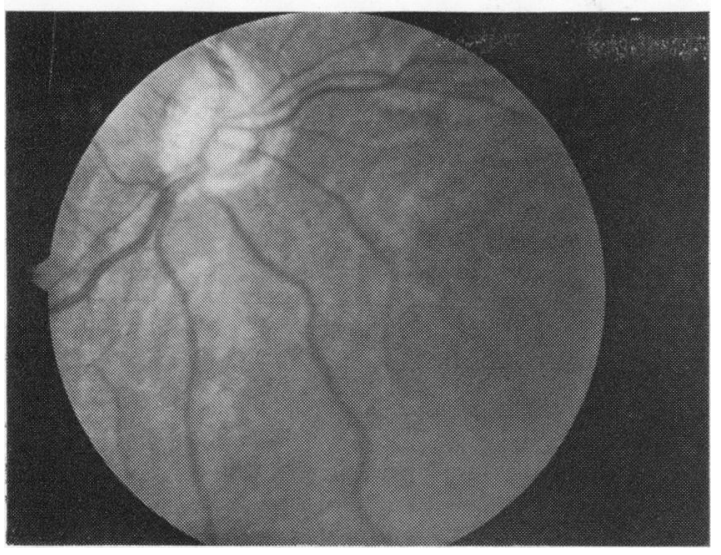

Fig. 2 Optic nerve of the right eye in case 5

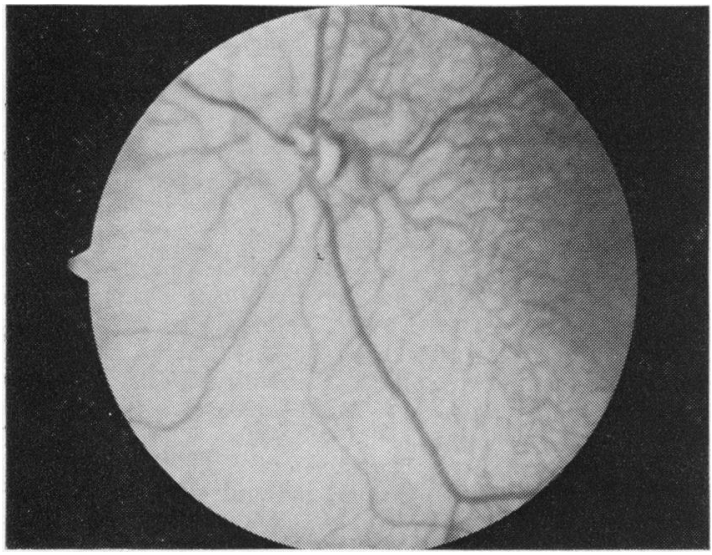

Fig. 3 Optic nerve of the right eye in case 1. The pigment border helps to define the small disc

stated that poor vision is an essential feature of optic nerve hypoplasia (Edwards and Layden, 1970). Optic nerve hypoplasia is clearly not a single developmental defect but a spectrum of disorders attended by a wide variation in visual dysfunction and associated conditions. The 7 patients reported in this paper highlight some of this variability. Nevertheless, they all share a single common feature: all were born of epileptic mothers taking anticonvulsants during pregnancy.

Most cases of optic nerve hypoplasia are sporadic, non-familial, and without any apparent cause. The search for causative factors must be directed at the early weeks of pregnancy, since the determination period for anomalies of the optic nerve occurs early in fetal development. Retinal ganglion cells differentiate during the sixth week of embryogenesis, and by the seventh week the ganglion cells are formed and the lumen of the optic stalk is almost entirely filled with fibres (Duke-Elder, 1963).

McKinna (1966) reported 6 cases of optic nerve hypoplasia in which there was a history of maternal ingestion of large quantities of quinine as an abortifacient early in the first trimester of pregnancy. The hypoplasia was bilateral and resulted in severe visual impairment in all of the patients. However, in 2 of the cases the ingestion of quinine did not take place until late in the first trimester of pregnancy, when the development of the optic nerves would have been already accomplished. Furthermore, the retinal vessels in the affected children were described as being narrow in calibre. In other reports of optic nerve hypoplasia the retinal vessels have been thought to be normal (Walton and Robb, 1970; Edwards and Layden, 1970; Billson, 1972; Petersen and Walton, 1977). The atypical features of this report are significant. Whether quinine ingestion early in pregnancy may be a direct causative factor of optic nerve hypoplasia remains undetermined in our minds. There was no history of maternal quinine ingestion in any of the 67 cases we studied.

Petersen and Walton (1977) described 17 children, born of severely diabetic mothers, who had segmental optic nerve hypoplasia. This type of optic nerve hypoplasia resulted in altitudinal or sector visual field defects, but did not impair central visual acuity. Only 3 of the cases were unilateral, but most of the bilateral cases did not show symmetrical involvement as judged by the visual fields. All of the mothers were insulin-dependent diabetics. None of the parents had any evidence of hypoplasia of the optic nerve, but 9 of the patients belonged to families with at least 1 other sibling similarly affected. We have seen 2 patients of diabetic mothers with this type of segmental optic nerve hypoplasia.

The possibility that anticonvulsants might be responsible for some congenital abnormalities was first suggested by Meadow (1968), who noted an apparent increased incidence of cleft palate, cleft lip, and congenital heart disease in children born of mothers taking anticonvulsants during pregnancy. A subsequent retrospective study (Speidel and Meadow, 1972) documented an increased risk of congenital malformations and perinatal mortality in children of mothers with epilepsy. The commonest anomalies associated with epileptic mothers were cleft palate, cleft lip, microcephaly, and congenital heart disease. Although the authors concluded that the malformations were the result of multiple maternal factors, they did suggest that anticonvulsant drugs might have a teratogenic action. The data from over 50000 pregnancies established that the malformation rates of children exposed to phenytoin during early gestation were greater than those of children of non-epileptic mothers or children 
of epileptic mothers not routinely taking phenytoin (Monson et al., 1973).

Phenytoin has been shown to have a teratogenic effect in experimental animals (Gibson and Becker, 1968). Furthermore, Mirkin (1971) has demonstrated the transplacental passage of phenytoin. Concentrations of the drug in the newborn babies' circulation were similar to those in the mothers'. It has been postulated that phenytoin may exert its teratogenic effect by its interference with folic acid metabolism. It has been shown by Pritchard et al. (1971) that maternal folate deficiency is commoner and more severe in patients taking phenytoin. However, they did not report that maternal folate deficiency was correlated with an increased incidence of fetal malformations.

So far there have been no reports of optic nerve anomalies in association with maternal anticonvulsant therapy. However, it is interesting to note that in case 3 described by McKinna (1966) the mother not only took a large dose of quinine but was also taking ' 4 or 5 grains of nembutal' daily throughout the pregnancy. A coloboma of the retina but not involving the optic nerve was reported in a child with multiple congenital defects born of a mother taking phenytoin, phenobarbitone, and primidone (Dabee et al., 1975).

The 7 patients described in this report were all born of mothers taking anticonvulsants during pregnancy. Although some of the mothers took more than one anticonvulsant, phenytoin was common to all the mothers. It has been proposed that seizure activity by itself may be teratogenic. In this regard it is noteworthy that 2 of the mothers in our study were seizure-free during pregnancy. It is also important to note that in 4 of our patients $(1,2,3$, and 5$)$ there were systemic anomalies which have been associated with maternal anticonvulsant therapy. Additional collateral evidence that anticonvulsant therapy played a role in the development of the malformations in these patients is found in the observation that 2 of them had siblings who had systemic anomalies (cleft palate and ventricular septal defect) which have been associated with maternal anticonvulsant ingestion.

All of the mothers of the patients reported in this communication took phenytoin during pregnancy. In the light of what is known about the incidence of other congenital anomalies associated with maternal phenytoin ingestion this would appear to be a significant aetiological factor in the optic nerve hypoplasia of these children.
We conclude, therefore, that phenytoin appears to have well-established teratogenic properties in man, and optic nerve hypoplasia may be one of the foetal malformations associated with maternal ingestion of phenytoin.

\section{References}

Billson, F. A. (1972). Clinical significance of optic nerve hypoplasia. Transactions of Asia-Pacific Academy of Ophthalmology, 4, 179-180.

Billson, F. A., and Hopkins, I. J. (1972). Optic hypoplasia and hypopituitarism. Lancet, 1, 905.

Billson, F. A. (1975). Hypoplasia of the optic nerve: clinical features and associated syndromes. Australian Journal of Ophthalmology, 32, 30-38.

Bistner, S., Rubin, L., and Aguine, G. (1973). Development of bovine eye. American Journal of Veterinary Research, 34, 7-12.

Dabee, V., Hart, A. C., and Hurley, M. (1975). Teratogenic effects of diphenylhydantoin. Canadian Medical Journal, 112, 75-77.

Duke-Elder, S. (1963). System of Ophthalmology, Vol. 3, 2nd ed., pp. 19-47. Mosby: St. Louis.

Edwards, W. C., and Layden, W. E. (1970). Optic nerve hypoplasia. American Journal of Ophthalmology, 70, 950-959.

Gibson, J. E., and Becker, B. A. (1968). Teratogenic effects of diphenylhydantoin in Swiss-Webster and $A / J$ mice. Proceedings of the Society for Experimental Biology and Medicine, 128, 905-908.

Hackenbruch, Y., Meerhoff, E., Besio, R., and Cardosa, H. (1975). Familial bilateral optic nerve hypoplasia. American Journal of Ophthalmology, 79, 314-320.

Kytilä, J., and Miettingen, P. (1961). On bilateral aplasia of the optic nerve. Acta Ophthalmologica, 39, 416-419.

McKinna, A. J. (1966). Quinine induced hypoplasia of the optic nerve. Canadian Journal of Ophthalmology, 1, 261265.

Meadow, S. R. (1968). Anticonvulsant drugs and congenital abnormalities. Lancet, 2, 1296.

Mirkin, B. L. (1971). Placental transfer and neonatal elimination of diphenylhydantoin. American Journal of Obstetrics and Gynecology, 109, 930-934.

Missiroli, S. (1947). Una nuova sindrome congenita a caratterie famigliare: ipoplasia del nervo ottico ed emiangopsia binasale. Bollettino d'Oculistica, 26, 683-698.

Monson, R. R., Rosenberg, M. S., Hartz, S. C., Shapiro, S., Heinonen, O. P., and Slone, D. (1973). Diphenylhydantoin and selected congenital malformations. New England Journal of Medicine, 289, 1048-1050.

Petersen, R. A., and Walton, D. S. (1977). Optic nerve hypoplasia with good visual acuity and visual field defects. Archives of Ophthalmology, 95, 254-258.

Pritchard, J. A., Scott, D. E., and Whaley, P. J. (1971). Maternal folate deficiency and pregnancy wastage. American Journal of Obstetrics and Gynecology, 109, 341-346.

Speidel, B. D., and Meadow, S. R. (1972). Maternal epilepsy and abnormalities of the fetus and newborn. Lancet, 2 , 839-843.

Walton, D. S., and Robb, R. M. (1970). Optic nerve hypoplasia. Archives of Ophthalmology, 84, 572-578. 